\title{
Fibroblast Growth Factor 7
}

National Cancer Institute

\section{Source}

National Cancer Institute. Fibroblast Growth Factor 7. NCI Thesaurus. Code C20436.

Fibroblast growth factor 7 (194 aa, 23 kDa) is encoded by the human FGF7 gene. This protein is involved in embryonic development, cell proliferation, cell differentiation, branch formation and keratinocyte growth. 